\title{
MEDICINE
}

\section{POSSIBLE ROLE OF NITRIC OXIDE IN REGULATION OF MICROCIRCULATION IN THE ORAL CAVITY TISSUES OF RAT}

\author{
${ }^{1}$ Dekanosidze M., ${ }^{1}$ M. D. Saganelidze Kh., ${ }^{2}$ M. D. Mamaladze M., \\ ${ }^{2} M$. D. Sakvarelidze N., ${ }^{3}$ Ph. D. Diasamidze G., ${ }^{1,4}$ Dr. S. Mitagvaria N., \\ ${ }^{I}$ New Vision University, \\ ${ }^{2}$ Tbilisi State Medical University, \\ ${ }^{3}$ Association of Dentists of Georgia, \\ ${ }^{4}$ Beritashvili Center for Experimental Biomedicine, \\ Georgia
}

DOI: https://doi.org/ 10.31435/rsglobal_ws/28022019/6353

\section{ARTICLE INFO}

Received: 12 December 2018

Accepted: 22 February 2019

Published: 28 February 2019

\section{KEYWORDS}

Nitric Oxide, L-NAME, local blood flow,

oral tissue, rat. \begin{abstract}
Possible role of Nitric oxide (NO) in terms formation of basal blood flow level in oral cavity tissue is studied using the method of hydrogen electrochemical generation in anesthetized rats.

It was found that NO plays a leading role in oral mucosa and submandibular gland basal blood flow regulation and does not have any significant effect on blood circulation of the lower snout tissue.
\end{abstract}

Citation: Dekanosidze M., $\quad$ Saganelidze Kh., $\quad$ Mamaladze M., $\quad$ Sakvarelidze N., $\quad$ Diasamidze G., Mitagvaria N. (2019) Possible Role of Nitric Oxide in Regulation of Microcirculation in the Oral Cavity Tissues of Rat. World Science. 2(42), Vol.2. doi: 10.31435/rsglobal_ws/28022019/6353

Copyright: (C) 2019 Dekanosidze M., $\quad$ Saganelidze Kh., $\quad$ Mamaladze M., $\quad$ Sakvarelidze N., Diasamidze G., Mitagvaria N. This is an open-access article distributed under the terms of the Creative Commons Attribution License (CC BY). The use, distribution or reproduction in other forums is permitted, provided the original author(s) or licensor are credited and that the original publication in this journal is cited, in accordance with accepted academic practice. No use, distribution or reproduction is permitted which does not comply with these terms.

Information about the role of L- arginine-NO system in the regulation of oral cavity vascular tone is very poor [7,9]. The only fact known about this regulation is that the tooth pulp is innervated by peptidergic afferent nerves [10], which are under mechanical and/or thermal stimulation, also it is determined that the diameter of the rat's incisors pulp arterioles is of caliber less than $100 \mu[6]$.

In the present work we used a strong inhibitor of Nitric Oxide (NO) biosynthesis $\mathrm{N}^{\mathrm{W}}$-nitro-Larginine Methyl Ester (L-NAME) in order to determine the role of NO in regulation of the intensity of blood flow in the rat oral cavity mucosa, lower lip and submandibular gland.

Material and methodology. The experiments were conducted in the rats with $350-400 \mathrm{~g}$ masses under the anesthesia with of chlorine hydrate $(4 \mathrm{mg} / \mathrm{kg})$. Polyethylene pipe was inserted into trachea of the animals for uninterrupted natural respiration. The animals' temperature was controlled rectally and its level was regulated at $37^{\circ} \mathrm{C}$ level by the electric heating blanket. Arterial pressure was measured on the tail artery. Dynamics of the local blood flow in the oral cavity mucosa, lower lip and submandibular gland was continuously recorded with hydrogen electrochemical generation method.

Protocol of the experiment. Experiments on the 15 groups of rats were conducted in 3 series. In each of the series 5 groups of animals (including one control) were studied, each group consisted of 6 animals (Table 1). 
Systemic arterial blood pressure and heart rate were measured in all of the series and all of the groups of animals. At the same time local blood flow was recorded in the oral cavity mucosa (I Series), lower lip tissue (II series) and submandibular gland (III series).

In the control group of animals of all the series, we intravenously administered $0,5 \mathrm{ml}$ physiological saline and recorded all of the listed indices.

In the first group of animals of all the series we intravenously administered $30 \mathrm{mg} / \mathrm{kg} \mathrm{L}-\mathrm{NAME}$, 30 minutes prior to introduction of L-NAME in the second group we intravenously introduced 300 $\mathrm{mg} / \mathrm{kg}$ L-Arginine; in the $3^{\text {rd }}$ group the L-NAME dosage was decreased to $5 \mathrm{mg} / \mathrm{kg}$, and in the $4^{\text {th }}$ group 30 minutes prior to introduction of the L-NAME reduced dose, $300 \mathrm{mg} / \mathrm{kg}$ L-Arginine intravenous injection was made. Both L-NAME and L-Arginine were solved in the physiological saline.

Table 1. Data concerning carried out experiments

\begin{tabular}{|c|c|c|c|}
\hline $\begin{array}{l}\text { Registered Indices } \\
\text { in all groups }\end{array}$ & Groups of animals & Experimental impact & $\begin{array}{l}\text { Number of } \\
\text { animals }\end{array}$ \\
\hline \multirow{5}{*}{$\begin{array}{l}\text { 1. Systemic arterial } \\
\text { pressure } \\
\text { 2. Heart rate } \\
\text { 3. Local blood flow }\end{array}$} & Control & $0,5 \mathrm{ml} 0.9 \% \mathrm{NaCl} \mathrm{i} / \mathrm{v}$ & 6 \\
\hline & $\mathrm{I}$ & 30mg/kg L-NAME i/v & 6 \\
\hline & II & $\begin{array}{l}300 \mathrm{mg} / \mathrm{kg} \text { L-Arginine and then } 30 \mathrm{mg} / \mathrm{kg} \\
\text { L-NAME } \mathrm{i} / \mathrm{v}\end{array}$ & 6 \\
\hline & III & $5 \mathrm{mg} / \mathrm{kg}$ L-NAME i/v & 6 \\
\hline & IV & $\begin{array}{c}\text { 300mg/kg L-Arginine and } 30 \mathrm{~min} \text { later - } \\
5 \mathrm{mg} / \mathrm{kg} \text { L-NAME } \mathrm{i} / \mathrm{v}\end{array}$ & 6 \\
\hline
\end{tabular}

After narcosis with chloral hydrate, we placed rats on the back, fixed the head with the experimental table holders, and the jaws were immobilized by a 1,5-2 cm stainless steel rod, which was temporarily secured between the upper and lower jaws by acryl. Blood flow measuring electrodes were placed in the corresponding tissue by selecting of vertical position of electrodes, with minimum damage to the tissue, without additional fixers. Very thin (15um) output golden wires did not limit the movement of electrodes along the tissue in the breathing rhythm, which greatly reduced formation of artifacts related to the movement.

Reference electrodes were secured subcutaneously, in the area of neck.

All the received data were recorded on the computer disk and their statistical analysis was performed using the software package PHARM.

Changes in local blood flow compared to the initial level were calculated in percentages.

Systemic blood pressure with "bloodless" method was measured discretely (in every 5-6 minutes) using the measuring device - "Arteria" developed by prof. G. Abuladze. The small size cuff was placed on an animal tail, which was continuously warmed up to $37^{\circ} \mathrm{C}$. The data was recorded by the oscillator. The systolic and diastolic arterial blood pressure was measured and then the average systemic arterial blood pressure was calculated.

The method also gives opportunity to calculate heart rate.

Hydrogen electrochemical generation method for local blood flow recording.

We recorded local blood flow using hydrogen electrochemical generation method [11], which is actually a modification of hydrogen clearance method [2] (see the scheme on the Fig. 1). When using this method, hydrogen is locally generated in tissue. The amount of hydrogen generated in accordance with the law of the Faraday is proportional to the intensity and duration of current in the generation circuit [1]. It is known that the hydrogen ions in the electrolyte solution will be reduced to the molecular hydrogen on platinum electrode if negative potential is applied to it. Therefore, if the electric current is passed between two electrodes placed in tissue, then around the platinum electrode atomic hydrogen will be formed, which will rapidly move into the molecular hydrogen. If the current intensity is not changed during the experiment, the amount of hydrogen generated in the electrode neighboring tissue will depend on the hydrogen diffusion in the surrounding area and the intensity of the blood flow, the latter providing active washing out of the hydrogen molecules. Since the first factor (diffusion) is permanent and its parameters do not change during the experiment, it can be assumed that change of the number of hydrogen molecules in the generation area actually depends only on the intensity of blood flow. Thus, through the second platinum electrode in the generation area, it is possible to measure change of hydrogen partial pressure, which is actually equivalent to recording of dynamics of blood flow change in tissue. 


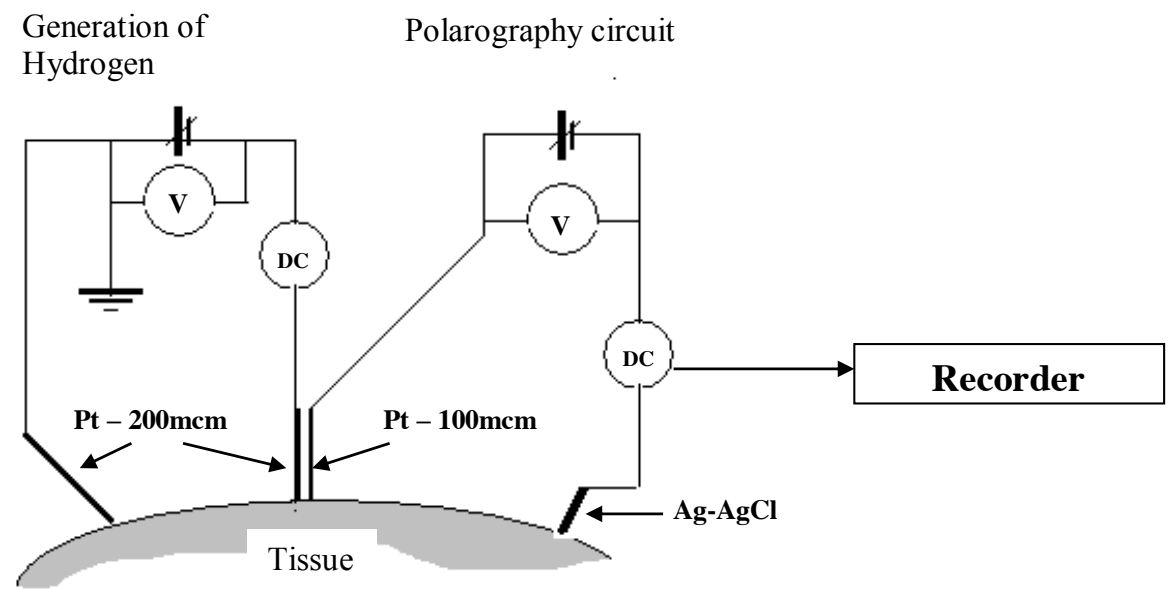

Fig.1. Principal scheme of the hydrogen electrochemical generation method measuring of the local blood flow in the tissue. Notations: $V$-voltage measurer, DC-direct current measurer, Pt-200mkm and Pt-100mkm - 200 and 100 um diameter platinum wires, $\mathrm{Ag}-\mathrm{AgCl}$-reference electrode of chlorinated silver. See the description in the text.

For recording of local blood flow, we have used a combined electrode of two platinum wires of $200 \mathrm{um}$ and $100 \mathrm{um}$ diameter spaced by 200-250um. Platinum wires of $200 \mathrm{um}$ diameter performs the role of generator and provides saturation of tissue with molecular hydrogen in the volume of $2 \mathrm{~mm}^{3}$. By 100um diameter measuring wire it is possible polarographically record the hydrogen tension.

In our experiments, current intensity of generation was $1 \mathrm{uA}$ and the polarization voltage was $200 \mathrm{mV}$. We used chlorinated silver $(\mathrm{Ag} / \mathrm{AgCl})$ wire of $2 \mathrm{~mm}$ diameter as the auxiliary electrode, which was secured under the skin in the neck area.

This method is used for both quantitative (impulse generation mode) and qualitative (continuous generation mode) measurements of local blood flow. Unlike other methods, it is characterized by a small inertia, measurement stability, and most importantly - possibility of continuous recording.

\section{Results. Changes in systemic arterial blood pressure and heart rate:}

Intravenous injection of $30 \mathrm{mg} / \mathrm{kg}$ L-NAME results in increase of average systemic arterial blood pressure by about $27 \%$ (Fig. 2). Its initial average level was $117 \pm 7 \mathrm{~mm} \mathrm{Hg}$, and after introduction of L-NAME $-148 \pm 6 \mathrm{~mm} \mathrm{Hg}$, the difference is statistically significant $(p<0,05)$. Maximum increase of pressure was recorded at 5-7 minutes after administration of L-NAME. At the same time, bradycardia was observed as well; initial heart rate was $420 \pm 12$ beats per minute, and after administration of L-NAME it became equal to $370 \pm 15$ beats per minute (Fig. 3). The difference here is also statistically significant $(\mathrm{p}<0.05)$.

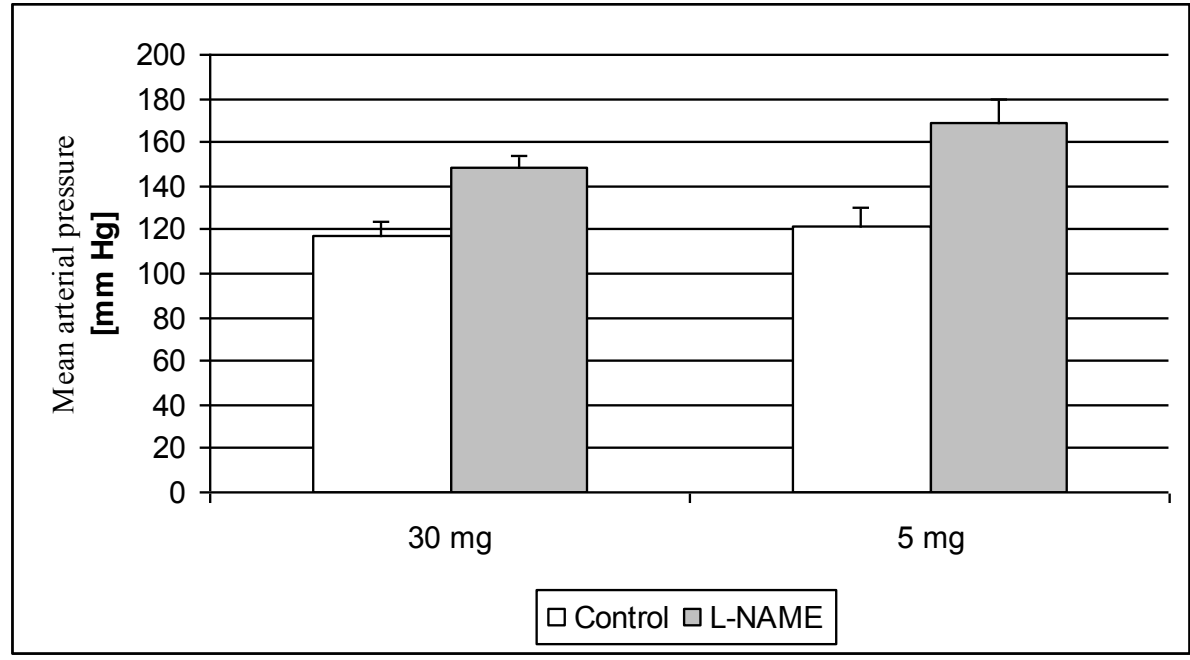

Fig. 2. Average arterial blood pressure values prior to intravenous administration of the two different doses of L-NAME (30 and $5 \mathrm{mg} / \mathrm{kg}$ ) (Control) and 5-7 minutes after the introduction. The difference in both cases is statistically significant $(p<0.05)$. 
Upon the background of prior introduction of L-arginine, introduction of the same dose (30 $\mathrm{mg} / \mathrm{kg}$ ) of L-NAME did not actually give any noticeable change in the pressure or heart rate.

The lower dose of L-NAME $-5 \mathrm{mg} / \mathrm{kg}$ caused increase of average blood pressure by almost $40 \%$. The initial average blood pressure in this group of animals was $121 \pm 9 \mathrm{~mm} \mathrm{Hg}$, and after introduction of LNAME it increased to $169 \pm 11 \mathrm{mmHg}$ (the difference is statistically significant $-\mathrm{p}<0.05$ ). In this case expressed bradycardia was also recorded. The heart rate decreased from $430 \pm 7$ to $385 \pm 12$ beats per minute.

Upon the background of prior introduction of L-arginine, neither this dose of L-NAME gave statistically reliable changes in average systemic arterial blood pressure or heart rate.

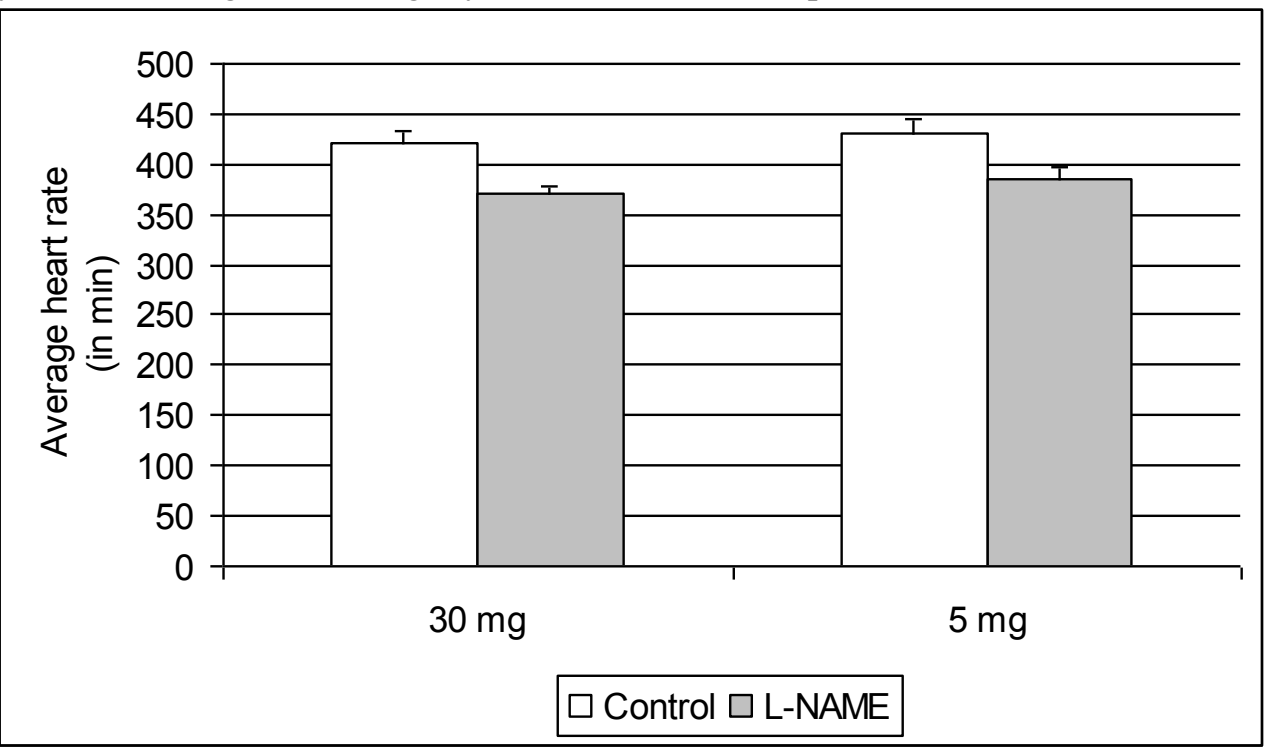

Fig. 3. Average heart rate values prior to intravenous administration of the two different doses of $L$ NAME (30 and $5 \mathrm{mg} / \mathrm{kg}$ ) (Control) and 5-7 minutes after the administration. The difference in both cases is statistically significant $(p<0.05)$.

\section{Changes of local blood flow in the different tissues of oral cavity:}

Intravenous injection of $30 \mathrm{mg} / \mathrm{kg} \mathrm{L}-\mathrm{NAME}$ in the oral cavity mucosa caused reduction in basal blood flow by average $38 \%$ and by $14 \%$ in the submandibular gland (Fig. 4). In both cases the data was statistically significant $(p<0,05)$. This reduction in both cases was recorded after the initial increase of blood flow, which according to our observation coincides with increase of systemic arterial blood pressure. As for the dynamics of the local blood flow in the lower lip tissue - it was practically unchanged.

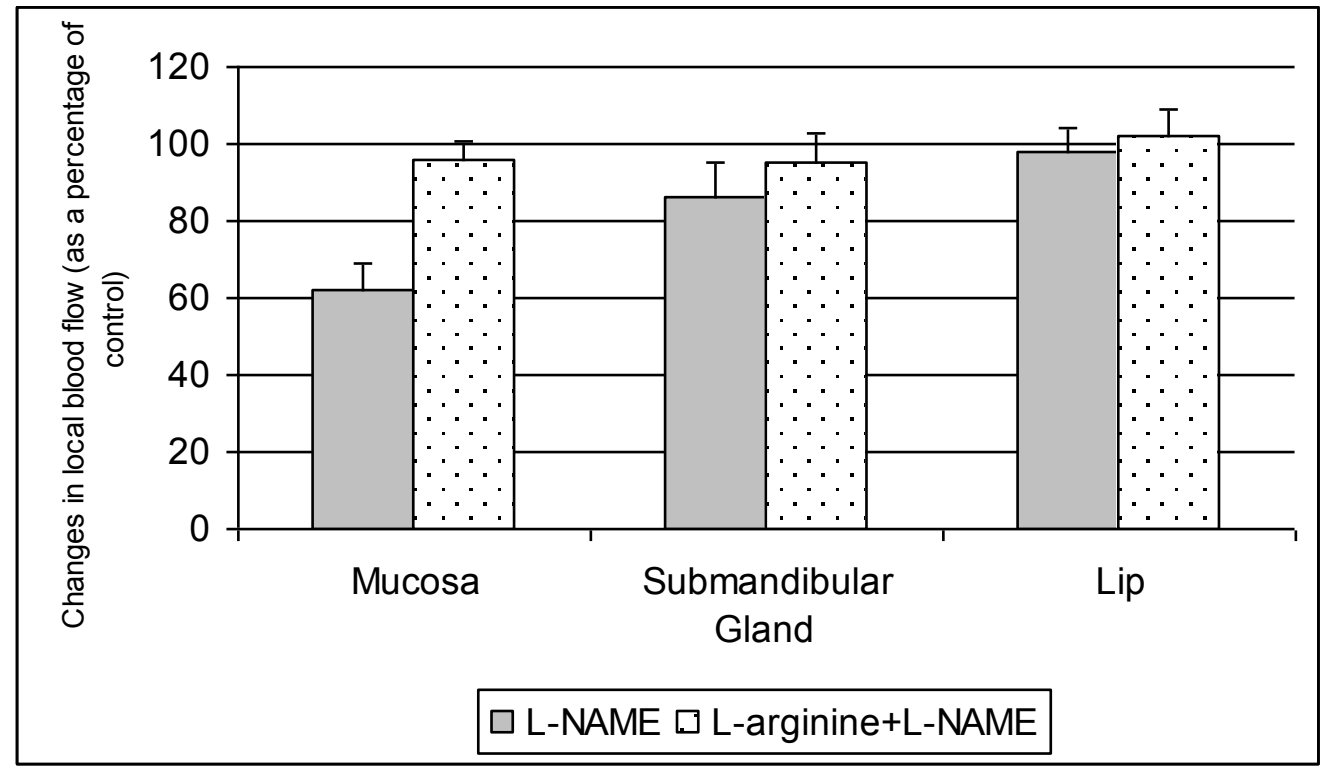

Fig. 4. Changes of local blood flow in the oral tissues (oral cavity mucosa, submandibular gland, lower lip) after L-NAME (30 mg/kg) intravenous administration (dark columns) and L-NAME administration with the same dose upon the background of L-arginine (300 $\mathrm{mg} / \mathrm{kg}$ ) prior administration (light columns). 
Similar results were obtained for the use of L-NAME with a lower dose $(5 \mathrm{mg} / \mathrm{kg})$ (Fig. 5). In this case, as well prior, administration of L-arginine prevented changes in local blood flow caused by L-NAME.

Administration of L-Arginine itself in the oral cavity tissues under study did not cause changes of local blood flow.

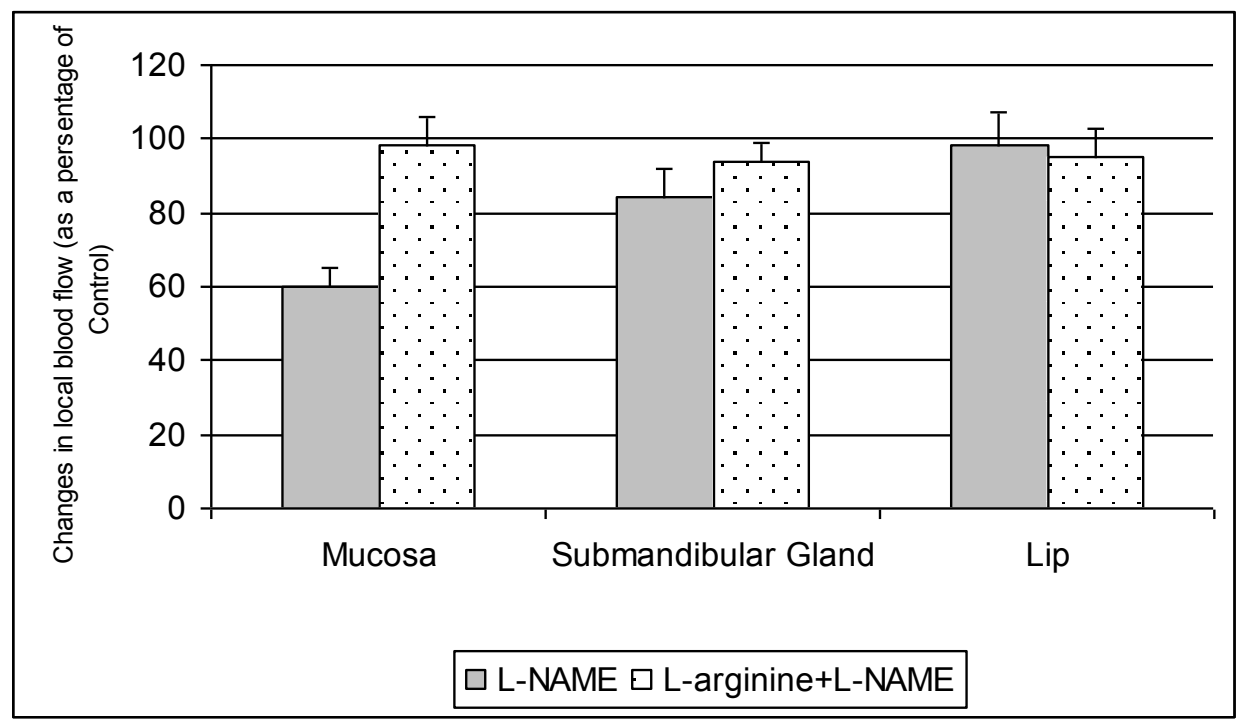

Fig. 5. Changes of local blood flow in the oral tissues (oral cavity mucosa, submandibular gland, lower lip) after L-NAME (5 $\mathrm{mg} / \mathrm{kg}$ ) intravenous administration (dark columns), and L-NAME administration with the same dose upon the background of L-arginine (300 $\mathrm{mg} / \mathrm{kg}$ ) prior administration (light columns).

Discussion. The results obtained confirm that pre-inhibition of the synthesis of Nitric Oxide leads to reduction of basal blood flow in the rat oral tissues that should mean that continuous formation of Nitric Oxide can control blood circulation in the oral mucosa and submandibular gland.

The inhibitor of the Nitric Oxide production L-NAME led to changes in systemic arterial pressure average level and heart rate, which are prevented by prior administration of L-Arginine.

It should also be noted that if administration of L-NAME caused reduction in local blood flow in the oral cavity mucosa and submandibular gland tissue, there was no change in the lower snout tissue.

In order to explain the mechanism of blood flow reduction, suggestion that it is caused by enhanced production of constrictor peptide endothelin, probably, is not applicable, as it was previously shown that the use of Nitric Oxide synthesis inhibitors does not enhance endothelin basal release [3]. Other considerations are also suggested that reduction of blood flow is initiated on the common carotid artery by the constrictor effect of L-NAME (Gardiner et al., 1991), but in our case this explanation is not applicable as well, since after the introduction of L-NAME basal blood flow in the rat lip did not change.

Based on the above, there is one logical conclusion that the described reduction of blood flow in oral tissues after administration of L-NAME can be attributed to the possibility of this substance to locally inhibit formation of Nitric Oxide [8]. This assumption is also confirmed by the fact that the prior introduction of L-Arginine caused removal of the effect. Although we did not draw attention to the source of Nitric Oxide in this paper, it is likely that we can suppose that it is excreted from the vascular endothelium and is a strong regulating factor of local blood flow in the oral cavity mucosa and submandibular gland. At the same time, the results obtained by us confirm that regulation of blood flow in the rat lip tissue should not be directly conditioned by Nitric Oxide. It is also noteworthy that the introduction of L-Arginine (direct donor of Nitric Oxide) did not cause any changes in the blood flow basal level neither in mucosa nor in submandibular gland. This fact indisputably indicates that the blood vessels are already dilated in the tissues under anesthesia (as previously indicated for the pulp blood flow - [4]) and there is enough quantity of this substrate that saturates NO-forming enzyme.

\section{REFERENCES}

1. Adams R.N. Ekectrochemistry at solid electrodes. New York, Marcel Dekker Inc., 1969.

2. Aukland K. Hydrogen polarography in measurement of local blood flow; Theoretical and empirical basis. Acta neurol. Scand., 1965, 41, 14, Suppl., p.42-45.

3. Boulanger C., Luscher T.F. Release of endothelin from the porcine aorta. Inhibition by endotheliumderived nitric oxide. J. Clin. Invest., 1990, 85, 587-562.

4. Edwall L. Some effects of sympathetic nerve activation in oral tissues as studied by tracer disappearance. Thesis, Stockholm, 1971. 
5. Gardiner S.M., Kemp P.A., Bennet T. Effect of N-nitro-L-arginine methyl ester on vasodilator responses to acetilcholine, 5'-N-ethylcarboxamidoadenosine or sambutamol in conscious rats. Br. J. Pharmacol., 1991, 103, 1752-1758.

6. Kim S., Lipowsky S., Usami S., Chien S. Arteriovenous distribution of hemodynamic parameters in the rat dental pulp. Microvasc. Res., 1984, 27, 28-36.

7. Koss M.C., Yu Y. Tole of Nitric oxide in maintenance of basal oral tissue blood flow in anesthetized cats. GENERAL Pharmacology, 2000, 35, 3, 159-164.

8. Rees D.D., Palmer R., Schulz H., Hodson H., Moncada S. Characterization of three inhibitors of endothelial nitric oxide syntheses in vitro and in vivo Br. J. Pharmacol., 1990, 101, 746-751.

9. Roberts Z., Koss M. Nitric oxide regulation of lingual blood flow in the rat. Nitric Oxide, 2001, 5, 271-277.

10. Silverman J.D. and Kruger L. An interpretation of dental innervations based upon the pattern calcitonin gene-related peptide (CGRP)-immunoreactive thin sensory axons. Somatosens. Res., 1987, 5, 157-164.

11. Stosseck K., Lubbers D.W. Determination of microflow of the cerebral cortex by means of electrochemically generated hydrogen. In: Brain and Blood Flow (Ed. R.W. Russel). London, 1970, pp.80-84. 